FACTA UNIVERSITATIS

Series: Law and Politics Vol. 14, No 4, 2016, pp. 515 - 529

DOI: 10.22190/FULP1604515A

Review Paper

\title{
FAMILIES AND MEDIATION: THE IMPACT OF VARIOUS MEDIATION STYLES IN CHILD CUSTODY CASES
}

\author{
UDC 347.918:347.64
}

\author{
Jelena Arsić \\ Faculty of Law, Union University, Belgrade, Republic of Serbia
}

\begin{abstract}
The child custody disputes may have different backgrounds, such as: divorce, guardianship, adoption, child abuse and neglect, etc. Quite often, however, parents separation and divorce raise the issue of child custody. Families dealing with these stressful life events face a tough time of insecurity and confusion. Studies have shown that the degree of cooperation or conflict between parents is the factor that significantly contributes to how the children will react to their parents' divorce or separation. Unfortunately, the adversarial process has not proven to be the best method to help parents to cooperate and support each other when the lives of their children are being discussed. In contrast to litigation, mediation has showed to be a process that diminishes negative consequences that often result from custody disputes. Mediation brings parents together, emphasizes their common interests, and helps them make decisions that will benefit the whole family. During the past few decades, international mediation practice has developed various mediation styles, nowadays used by mediators to manage different types of disputes. This paper will address one of the most discussed classifications of mediation styles with an effort to reach conclusions on the most appropriate approach to mediating child custody disputes.
\end{abstract}

Key words: child, parent, custody dispute, mediation, mediator style

\section{INTRODUCTION}

All disputes are matters of human relationship, and all human relationships are almost unbelievably complex (Friedman, 1993: 8). Families going through separation and divorce deal with a tough time of insecurity and confusion. These highly emotional events are very difficult for parents, but particularly affect children who are unprepared for and terrified by all the changes that separation brings (Wallerstein, 2000; Saposnek, Rose, 2004). When

Received December $14^{\text {th }}, 2016 /$ Accepted December $27^{\text {th }}, 2016$

Corresponding author: Jelena Arsić, LL.D.

Faculty of Law, Union University, Goce Delčeva 36, 11070 Belgrade, Republic of Serbia

E-mail: jelena.arsic@pravnifakultet.rs 
their parents' relationship starts to fall apart, children become frightened, sometimes even angry. Parents' love and support becomes their biggest need. They seek an explanation about what is going to happen and a guarantee that they will not lose either parent after separation (Saposnek, 2003). Sadly, parents often fail to respond and to protect their children from these adult-related issues. Lost in the efforts to put pieces of their lives back together, they forget that they are the children's role models. They fail to recognize how important it is for children to look at them and see that life is good, and that everything will be fine. Instead, the parents' conflict often turns into a battle in which each parent tries to defeat the other and, eventually, child is the one who pays the price for the failure of the adult relationship.

The child custody disputes may have different backgrounds such as divorce, guardianship, adoption, child abuse and neglect, etc. Quite often, however, divorce is the event that raises the issue of child custody. Each year in Serbia there is a number of divorcing parents in a dispute about custody. ${ }^{1}$ Having in mind the significant case load of Serbian courts and the lack of efficiency of court procedures, it could be said that contested custody cases developed into an everyday event. When parents decide to divorce, some other issues have to be resolved as well, such as: property distribution, alimony and child support. However, it seems that the issue of child custody is often the most sensitive of all considering the potential for harm which seems to be associated with the processing of divorce cases through the adversarial system (Clarke-Stewart, Brentano, 2006). ${ }^{2}$

Studies have shown that the degree of cooperation or conflict between parents is the factor that significantly contributes to how the children will react to their parents' divorce or separation; namely, more parental cooperation generally results in easier acceptance by the children (Saposnek, 2003). Unfortunately, litigation has not proven to be the best method to help parents cooperate and support each other when the lives of their children are being discussed. Quite often, the courtroom becomes the field for custody battles. These are disputes that Donald Saposnek, a clinical child psychologist and mediator, ironically calls "seeking the judge's Academy Award for 'best parent' in a past role of marital partner" (Saposnek, 2001). Because of this, some authors also describe custody litigation as "the ugliest litigation" (Goldzband, 1985: 21). It is filled with accusations, anger, stress and other negative emotions which only increase the animosity between parents, and it has the most damaging effects on children.

In contrast to litigation, mediation has proved to be a process that diminishes the negative consequences that often result from custody disputes. Mediation brings parents together, emphasizes their common interests and helps them make decisions that will benefit the whole family. Mediation is an alternative dispute resolution process in which the mediator, as a third neutral party, facilitates communication and negotiation between parties to assist them in reaching a voluntary agreement regarding their dispute. ${ }^{3}$ In child

\footnotetext{
${ }^{1}$ Only in 2014 there were 7,614 divorces in Serbia; the number increased in 2015, showing 9,384 new divorce cases. In more than $50 \%$ of these cases (5,288 divorces in 2015), spouses have children (Statistical Office RS, 2016).

${ }^{2}$ Analyzing the issues of divorce and related custody disputes in the United States, Andrew Schepard, inter alia, emphasis that: "1) parental divorce has increased dramatically during the twentieth century to the point where it is a predictable event in the lives of a large percentage of children; 2) the increasing divorce rate parallels a dramatic increase in the caseload of the child custody court; 3) most parents who bring their disputes to the court are pro se either because they cannot afford a lawyer or because they fear that lawyers will involve them into endless conflict; 4) the public is deeply dissatisfied with the child custody court and adversarial process for resolving child custody disputes". (Schepard, 2004: 27). Similar statements could easily be used today to describe fundamental issues in this field in Serbia.

${ }^{3}$ Article 2. Mediation Act (Zakon o posredovanju u rešavanju sporova), Official Gazette RS, 55/2014.
} 
custody cases, such an agreement is a parenting plan that states how the parents will share responsibilities regarding their children. ${ }^{4}$

During the past few decades, international mediation practice has developed different mediator styles and techniques. This paper will address one of the most discussed classifications of mediating approaches: the facilitative, evaluative and transformative mediation, based on the theories that serve as guiding principles for various mediator interventions. Each of these mediation styles will be presented in a hypothetical child custody case, with an effort to reach conclusions on the most appropriate technique for mediating child custody disputes.

\section{STYLES OF MEDIATION}

In many countries, throughout the years, mediation has proved as the best alternative to custody litigation. With the help of a mediator, parents can choose a parenting agreement that would meet their own and their children's interests and needs, and at the same time avoid the economic and emotional costs that litigation carries.

However, just as custody litigation was and still is a subject of debate, mediation as well has raised a lot of controversial issues. Should mediation in custody cases be mandatory or voluntary? Is mediation appropriate in cases of domestic violence? Should children participate in mediation and what is the most appropriate way to involve them in the process? Should mediation allow involvement of the third parties, such as grandparents, step-parents and other relatives? What is the role of attorneys in mediation? What is the role of a family mediator? And, related to this, how might different mediator styles affect this role and mediation practice? This last controversy continues to be a subject of various analysis and discussions among mediation professionals (Alfini, 1991; Riskin, 1996; Zumeta, 2000).

\subsection{Facilitative mediation}

In the 1960s and early 1970s, mediation has exclusively been taught and practiced in the form of facilitative mediation. The facilitative style was the original concept of mediation, and it has been well known since the very beginning of the mediation movement in the United States. When the first community mediation centers were started, their approach was strictly facilitative (Zumeta, 2000: 335). Most of the mediators in these centers were volunteers, and they were not required to have substantive expertise concerning the area of the dispute (Zumeta, 2000).

The facilitative technique assumes that the mediator shapes the mediation process in order to help the parties reach a mutually acceptable agreement. The mediator "asks questions, validates and normalizes parties' points of view, searches for interests underneath the positions taken by the parties, and assists the parties in finding and analyzing options for resolution of their dispute" (Zumeta, 2000). In order to enable the parties to make fullyinformed decisions, the facilitative mediator prefers to hold joint sessions. However, if needed, the mediator might use caucuses ${ }^{5}$ as well.

\footnotetext{
${ }^{4}$ Family mediation has also been used for resolving other divorce-related issues such as distribution of marital property and spousal support. See: Art. 241. Family Act (Porodični zakon), Official Gazette RS, 18/2005, 72/2011 and 6/2015.

${ }^{5}$ Caucus is a private session in which the mediator meets with one of the parties without the other party being present. Information gathered during the caucus is confidential and mediator may use this information in joint sessions only if parties agree to that.
} 
This type of mediation fully recognizes parties' self-determination. Therefore, the facilitative mediator is not willing to make any recommendations to the parties, and does not give his advice or opinion with regard to the outcome of the case. The main goal is for the parties to reach a mutually acceptable agreement which is why in facilitative mediation the mediator controls the process, while the parties control the outcome (Zumeta, 2000).

Supporters of facilitative mediation often emphasize that this approach leaves possible solutions only to the parties, and claim that mutually acceptable solutions are enhanced by focusing on the parties' real interests and needs. On the other side, critics say that with this approach to the mediation process may take too long and may lead to unfair results since the mediator relies on the parties' ability to resolve their own conflict.

\subsection{Evaluative mediation}

In the 1980s and 1990s, mediation was supported in most of the states in the USA and a great number of court cases were referred to mediation (Levin, 2001: 267). At that time, settlement conferences were mainly held by judges, and that is how evaluative mediation developed. This approach is based on the principle that parties benefit when an experienced and objective third party provides guidance about substantive issues and merits of their positions (Levin, 2001: 268).

The main purpose of evaluative mediation is to help the parties evaluate their legal positions, rather than reach a settlement. This is why the evaluative mediator uses a lot of caucuses, and the process is more focused on the parties' legal rights than on their interests and needs. The mediator assumes a judge-like role by pointing out the strengths and weaknesses of each party's position; he/she gives advice and opinion about how a judge would possibly decide the case. These evaluations are often based on legal principles or the principle of fairness. 6 Therefore, in evaluative mediation, the mediator structures the process and directly influences the outcome (Zumeta, 2000).

The evaluative style is often criticized because it ignores emotional aspects of the dispute which is very important in cases where the post-mediation relationship exists. It is also emphasized that this approach reduces the parties' self-determination, and that evaluations given by the mediator might affect his neutrality. The very directive approach that evaluative mediator has exerts pressure on the parties to reach an agreement, and the agreements reached in this manner might not last long. However, supporters argue that it is possible to provide the parties with basic legal information and evaluation without violating the mediator's impartiality, and that in evaluative mediation resolution is reached more quickly.

\subsection{Transformative mediation}

Transformative mediation is based on the concept founded by Joseph Folger and Baruch Bush in 1994. Transformative theory emphasizes the power of mediation as a process than can acquire more than just a settlement (Baruch Bush, Folger, 1994; Baruch Bush, 2001). The main goal of mediation is to transform the negative interaction between the parties in conflict into a positive relationship based on mutual empowerment. This process of "empowering" the parties leads them to the "recognition" of each other's points of view. "Empowerment" and "recognition" are the most important elements of transformative mediation. Through this process, people in conflict are transformed from angry, foolish or

\footnotetext{
${ }^{6}$ It is common for evaluative mediators to be lawyers or retired judges with substantive legal expertise.
} 
stubborn people to people who have come to an agreement because the other party understands their needs and interests. In order to achieve this, transformative mediator avoids the use of caucuses. Mainly, mediation completes in joint sessions. The purpose of "empowerment" is also to change how disputants deal with conflict in the future in order to allow them to handle conflict in general (Baruch Bush, Folger, 2005: 52).

In transformative mediation, parties shape both the process and the outcome. The mediator follows their lead and, hence, his or her role is passive (Zumeta, 2000). Supporters of transformative mediation say that this model gives more autonomy to the parties in making decisions about their future. It teaches the parties how to recognize and understand each other's needs and interests, and provides them with skills that they can use for resolving future conflicts. With this, transformative mediation promotes the long-term cooperation between the parties. Finally, the settlement that is reached through this type of mediation is more likely to serve the parties' interests and, therefore, lasts longer. Opponents say that this model is too idealistic in cases where the nature of the dispute requires a more directive approach, e.g., in cases involving power imbalance. They also argue that by allowing the parties to structure everything, the process might take too long and might not result in an agreement.

\section{IMPLEMENTATION OF VARIOUS MEDIATOR STYLES IN A CUSTODY CASE}

During the last couple of decades, mediation has developed into the best way for parents to learn how to manage their conflict for the good of the child. However, because of their highly emotional nature, child custody disputes represent the most challenging cases seen in family mediation (Saposnek, 1995: 14). It is often said that the goal of custody mediation is for the parties to reach a parenting agreement that will serve both them and their children. In addition, through mediation parents have the opportunity to discover how important cooperation and support are in the future. Yet, how the agreement is reached is often as important as the agreement itself (Friedman, 1993: 7), and the techniques used by the mediator to manage this can be of a great significance.

What follows is a hypothetical child custody case that will be used as basis to explain the practice of facilitative, evaluative and transformative approach in child custody mediation. For the purpose of this paper, it will be assumed that each mediator uses only one technique through the whole mediation process even though this would be rare and certainly difficult to apply in practice. Also, it will be assumed that mediation is already at the stage when the parties are giving their first statements and follows through to the stage of generating options. Everything written is a product of the author's view about how the following hypothetical case might progress in each of these mediations depending on the approach used by the mediator.

\subsection{Custody case study: The story of Iva and Sasa7}

Iva was only 17 when she met Saša. Saša was 25 years old. He was funny, patient and tender, totally different from her. They immediately fell in love with each other. Saša had a job in the insurance company while she worked in a bookstore. After dating for a few months, they were both so in love and nothing could stand in their way. They rented a

\footnotetext{
${ }^{7}$ This case is taken from the author's paper "Transformativna teorija konflikta i medijacija" (Transformative Theory of Conflict and Mediation), 2009: 170-180.
} 
small apartment in the suburbs and started living together. Soon after, Iva got pregnant and quit her job since Saša's salary was good enough for her to stay at home and raise their child. They were planning to get married. But Saša got a new job out of state, and had to relocate. Iva was full of understanding. So they made a pact: he would move to start a new job and try to find a place for them to live. She would then come and they would marry. They were separated for a few months but talked on the phone every day, and could not wait to be together again. Saša was happy with his new job. He was very busy trying to earn enough money to rent a decent apartment for Iva and him. One day after work, he ran into his old girlfriend Ana, a girl that he once loved and that dumped him for someone else. She was single again. With Iva far away from him, he started seeing Ana occasionally. He still had strong feelings for Iva and did not want to tell her anything. For him, the relationship that he had with Ana was only a temporary thing. He still planned for Iva to come as soon as he finds an appropriate place for them. But Ana got pregnant, too, and insisted that Saša leaves Iva. He did not know what to do and decided to tell Iva everything. At that time, she was seven months pregnant. Iva was heartbroken. She was angry, disappointed and did not want to hear from him anymore. Saša still hoped that she just needed some time to forget everything that had happened, and that eventually she would give him another chance. In the meantime, he chose to be there for Ana with whom he now also expected a child.

Saša was trying to reach Iva many times, but she would never respond. Finally, after a few months, she allowed him to see his two-month-old son Dušan. Saša was thrilled. At the beginning, he was able to see Dušan whenever he wanted and he regularly paid support for him. He even returned to his old job in order to be closer to his son. For four years, he would spend time with Dušan every weekend. They had a great relationship and Saša truly enjoyed father's role. He also had a son with Ana but would never talk with Iva about him. He knew that she would never forgive him for what he had done.

Saša would also spend time with his other son while Ana was trying to convince him to start living with her. When Dušan was about five years old, Saša moved in with Ana. He did not mention anything to Iva. But when Iva realized that Saša and Ana are together again, she stopped allowing his visits to Dušan. Even though Saša was paying child support on a regular basis, he could not convince Iva to allow him to see Dušan. In order to be able to maintain a loving, healthy relationship with his son, Saša knew that he has no other choice but to file a complaint to establish his partial custody rights. At the preliminary hearing, the judge referred them to mediation.

\subsection{Facilitative approach}

Mediator: I hope that we can start now. Who would like to go first?

Iva: Maybe it is better if he does.

Saša: Iva and I have a five-year-old son Dušan. She does not allow me to see him. I haven't seen him for two months already.

Iva: You know why you can't see him. It is because of her.

Mediator: Who is "her"?

Iva: His girlfriend Ana. They live together. She is crazy. She keeps calling me all the time and threatens that she will hurt me if I try to get back with Saša. I don't want him to take my son to that house.

Mediator: Saša, what is your response to this? 
Saša: Well, I want to be able to see my son. He has a three-year-old brother Luka, and I want Dušan to meet him. I know that Ana can be tough sometimes, but she really isn't a bad person.

Iva: I don't care what you think! You and she did enough already in the past. I did not ask you to come back, Saša. You chose to do that.

Saša: What are you talking about? Ok, I did a bad thing. But that was four years ago. I have always been there for you and Dušan. Now, for some reason, you don't allow me to see him anymore.

Mediator: Is it helpful to go back and talk about the past, or maybe it would be more productive to talk about your child and concerns that you have?

Iva: I am concerned that if he takes Dušan to that house, and Ana is there, she might hurt him. I don't trust her.

Mediator: Iva, I hear that your main concern is Dušan, not Saša as a father.

Iva: Saša has always been a good father to Dušan. But he does not know how to deal with her. I am afraid that he might not be able to protect Dušan.

Saša: I knew that you had a problem with her. Why didn't you say that earlier? Maybe I would understand then. For two months you don't give me any explanation.

Iva: Why would I? You probably would not listen. You always play by her rules. You did that in the past. Why would I believe that it would be different now?

Saša: That is nonsense. I never played by her rules. What are you talking about? How many times do I have to explain to you, I can't change the past!

Mediator: We are playing the "blame game" again. You think that what she is saying is ridiculous and you, Iva, think that he is ridiculous. The problem of the adults has become the problem of the child. Is that fair to a child?

Saša: I don't want us to talk about the past. I know that does not help Dušan. He needs both of us. And I understand that Iva is concerned about Dušan's safety. She is a mother. That is natural. Iva: What do you want then?

Saša: I want to be able to see him. I want to spend time with him on weekends because I am working during the week.

Iva: I want to have him on weekends, too. I also work and hardly see him during the week.

Saša: That is not true. Sometimes you work on Saturdays and then you have days off during the week.

Iva: Well, I am never sure when that's going to happen. It depends on my employer.

Mediator: Maybe we can start thinking how you can share your time with Dušan during the first month and then we can go from there. I assume that you both know your work schedule for the next month?

Saša: Yes.

Iva: I am not sure. I have to think.

Mediator: I have a calendar here. You can simply check the dates when each of you has time for Dušan. That way we can all have a better picture. Do you want to try that?

Saša and Iva: Yes.

Mediator: Ok.

When they went through all the dates they found out that there were some days when Iva was working and Saša had a day off and vice versa.

Mediator: Do you now think that it would be possible to work something out?

Iva: Perhaps Saša can spend time with Dušan when I am at work and, then, maybe on weekends we can spend time with Dušan together.

Mediator: Saša, what do you think?

Saša: I don't have a problem with that.

Iva: But if I am not there you have to be with him all the time, Dušan. And that can be only during the day when Ana is at work. I am still not comfortable with Dušan spending night at that house. 
Mediator: Saša, would you accept this?

Saša: Well, for now I'm fine with that. But I hope that after some time she'll be ok with his overnight stays, too.

Iva: If everything goes well, I am sure I will. Right now, I just need time.

Mediator: There are a lot of decisions that you have to make for your child in the years ahead. The more you can cooperate in making these decisions, the healthier the child will be. I am glad that we have made progress today. I can see that you both love Dušan very much and that you want best for him. This is very important step for all of you.

\subsubsection{Analysis}

During the session, the mediator was very active. The mediator would often reflect and summarize what parties were saying in order to put their words in more neutral context. He wanted to make sure that parties understood each other. The mediator would also acknowledge their feelings. That also helped them recognize each other's point of view. Saša said that he understood Iva's concerns about Ana, while Iva admitted that Saša was a good father. When Saša and Iva started arguing about the past, the mediator would remind them that going over the past was not helpful and that they had to focus on the future in order to resolve their conflict. The mediator would always place the child in that context. Each time this would take the parents off guard and they would start to move toward an agreement. The mediator also helped in the process of analyzing and finding options. When they did not agree on the time that each would have with Dušan, the mediator offered them a calendar. Saša and Iva found out that there were solutions that could work for both of them. The mediator never gave any legal opinion on the possible outcome of the case. He acknowledged the parties feelings, searched underneath their positions to identify their interests and needs, and suggested some options. It seemed that all the tools he applied were good enough to get Saša and Iva closer to their agreement, which was the mediator's main intention.

\subsection{Evaluative approach}

Mediator: Saša, since you are the one who filed a lawsuit, tell me what brought you to mediation? Saša: I'm here because I want to see my son Dušan. He's five years old. We have a lovely relationship. He recognizes me as a father. I was there for him from the day he was born. I even pay child support for him. Now Iva doesn't allow me to see him. I haven't seen my son for two months. Mediator: And why is that Iva?

Iva: Because I don't think that he is capable of taking care of Dušan. Therefore, I don't see a reason for us to be here today.

Mediator: You are here to try to resolve a conflict you have, to try to work out a parenting agreement. If you don't do that, the judge will do it for you. This is your opportunity to reach an agreement that will serve both of you.

Iva: I don't care. I am ready to litigate. This is my child, and I know what is best for him.

Saša: Dušan is not just your son. I am the father. Don't forget that. You have him all the time. I want to be able to see him as well.

Iva: You can always see him at my house.

Mediator: You have to know that every child needs to have both parents. Don't forget that this is not about you and the adult issues that you have. It is about your child and his stability. Dušan needs stability in his life. Your arguing does not help Dušan. 
Saša: I know that but she is so stubborn that she does not want to allow me to see my son. Dušan needs me and I need him.

Iva: I've already told you that you can see him if you're willing to come to our house. I don't want you to take him to your house where Ana is. I don't trust her. She is crazy!

Mediator: Who is Ana?

Saša: Ana is my girlfriend. We live together. Iva and Ana don't like each other.

Iva: That's true, I don't like her. She makes threats all the time. I know that she would do something bad to Dušan first time when you turn your back. And you would not be there to protect him.

Mediator: Saša, what do you have to say?

Saša: Ana is tough, but she's not a bad person. She would never do something like that. Besides, I would always be in the house if Dušan were there. I would like to see him only when I am not working which would be on weekends.

Mediator: Iva, if Saša is in the house, do you still see a problem?

Iva: Yes! I've already told you that he cannot watch Dušan all the time. At some point, he would stay alone and she might hurt him.

Saša: The things that you are saying are just nonsense. I would never leave him alone. He is five years old. Don't you think I know that?

Iva: I told you already, I won't change my mind. Even if we have to go to court!

Mediator: Let me explain to both of you what can happen in court if you do not agree here. The judge will not consider what you Iva think about Ana, whether she is crazy or not. The judge will try to determine what is in the child's best interest and, in your case, that would likely be for Dušan to spend time with his father as well. The court will consider that Saša and Dušan have had a loving relationship for the last four years, that Saša has never been abusive and in a situation to do any harm to Dušan. The court might as well take into account that Saša pays child support regularly from the day Dušan was born. It will not consider the fact that Iva does not like Ana and whatever happened with you two in the past. As long as Saša can provide a stable environment for Dušan, the court is likely to allow Saša to exercise his partial custody rights on the days when he has him. $\mathrm{He}$ is the father and therefore, entitled to all of that. Do you both understand?

Saša: I know that. But she obviously doesn't.

Iva: Even if Saša is considered as a good father, she is not a stable person. And Saša lives with her. I am sure that the court will consider that.

Mediator: Again, I am telling you that if you do not have any evidence that would prove that Dušan would be in danger when he is at Saša's house, it is unlikely that the court would deprive Saša of his right to see Dušan. Is there any way for you to work this out so that Dušan can see both of his parents?

Saša: When I say that I'd love to spend time with Dušan, I don't mean to take him to my house every time. I'd like to take him to the park, for example. The important thing for me is to spend time with my son.

Mediator: Would that be only on weekends?

Saša: I don't work on weekends. So that would be best for me, but I am willing to consider other options.

Mediator: What do you think, Iva?

Iva: I am OK with Saša taking Dušan to the park, but I don't want him to take Dušan to his house. By the way, I am working during the week, too. I practically don't see my kid during the week. I want to be with him on weekends as well.

Mediator: Saša, are you available during the week?

Saša: I can pick him up after work but then I'd like to have him over night, and I know that Iva will not allow that. 
Iva: You bet I won't!

Mediator: Ok, I think I would like to talk with each one of you separately now. This is just for me to gain some more information from you. Everything that happens during the private session will be confidential, and I will share it with both of you when we come back only if you allow it. Are you ok with that?

Saša: Yes.

Iva: Yes

\subsubsection{Analysis}

In this mediation, the mediator was very directive during the whole session. The mediator would speak often and did not allow the parties to get into a long argument. Almost at the very beginning of the session, the mediator reminded the parties that if they do not resolve their conflict they will end up in court and the judge will do it for them. During the session, the mediator focused the parties exclusively on the issue of custody arrangement. The mediator did not acknowledge the parties' feelings or any other underlying issue. The mediator also gave his opinion on the outcome that the case would likely have in court. Finally, the mediator decided to caucus, which is one of the main tools used in evaluative mediation. There is a possibility that this case would be resolved eventually, probably because Iva would change her mind knowing that she might lose in court. The mediator would use the caucus to repeat that information. But it is uncertain for how long such an agreement would work in practice. In other cases, some of the evaluative tools might be helpful for the parties to understand their positions. This particular case carries a lot of underlying emotional issues that have to be resolved in order for the parties to reach a parenting agreement that would meet their needs in the future.

\subsection{Transformative approach}

Mediator: Where would you like to begin?

Saša: Well, Iva and I have a five-year-old son Dušan. Since Dušan was born, I was seeing him practically every weekend, but now I haven't seen him for almost two months. She doesn't allow me to see him at all. I can't even talk with my kid over the phone. I want to be there for him, I'm his father you know...

Iva: Yes you are, but I don't think that you are capable of taking care of him. I don't even know why we are here today.

Mediator: You are here today to try to do the best for your child. You know Dušan better than anyone else and you both want the best for him. That is why you should make decisions about your child, not the court. You are here to make a parenting plan that will work for all of you. Mediation as a process gives you that opportunity.

Saša: That's why I am here. I think that Dušan needs his dad as much as he needs his mom. And I want to be able to spend time with my kid. She is the one that is so stubborn and refuses to allow that.

Iva: I am not stubborn! And even if I am, I don't care. My child is the most important thing to me! You want to see Dušan? You are always welcome to come and see him at my house. You know that.

Mediator: Saša, how do you feel about this?

Saša: Well, I feel that she forgets that I have been there for her and Dušan all these years. It's not just that I was paying support for him. I was there every time she needed me, taking Dušan to the doctor when Iva didn't have time. He is not only her child, you know. It is not enough 
for me to see him only at your place, Iva. I want to take him for a walk, I want to go and play with him in the park. I want to do everything that normal parents do, as I was doing all these years. I want him to meet his brother.

Iva: He can't meet his brother because it would mean that you'll take him to your house and Ana is always there.

Mediator: Iva, who is Ana?

Iva: Ana is his girlfriend. And they live together. Ana and I have never had good relationship. Saša: Why is Ana suddenly a problem? You have never told me that before. She is only your excuse to prevent me from seeing my kid.

Mediator: Help me understand, this should be about you and your child, not about other people. I noticed that outside in the lobby you were sitting together, you were laughing. To me, you did not look like people who were having any problems. Other than in this room, it seems to me that you still have a nice time when you are together.

Iva: Yes, we do. The thing is... I don't really have a problem with him. And I know that he loves Dušan. Saša was really there for us all these years. It is just her! She is my problem! And I am afraid that she might do something to Dušan if Saša takes him to her house.

Mediator: Iva, I hear you saying that you don't think that Saša is not a good father but that you have concerns about Dušan's safety at Saša's house because of Ana? Saša, what can you say about that?

Saša: Well, Ana can sometimes be a little bit hard, but she is not a bad person. I doubt that she would ever hurt Dušan.

Iva: Oh, yes she would. You know that she used to call me when we were still together, and she kept threatening me. She would do something just because she hates me. Saša is not my problem, she is! Everything would be different without her.

Mediator: Saša, can you think of anything that would dispel Iva's concerns?

Saša: Well, I might accept not taking Dušan to the house, at least at the beginning, if that would make Iva less concerned. I understand that Ana did some bad things during the past few years and Iva is now scared. But I don't want this to be a problem that would prevent me from spending time with my child.

Iva: If you want to see him, you can always come to visit him. We can even take Dušan to the park together. Just do not take him to your house! I'm really not comfortable with that. Not now, when he is only five years old.

Mediator: Saša, would you be comfortable with that?

Saša: Well, I think we can try. That way, at least, Dušan would be able to spend time with both of us. And I think that would make him happy. My child is really the most important thing to me. I don't want him to suffer because we have issues.

Iva: I don't want that either. You know that I don't think anything bad about you as a father. I know that Dušan loves you, and he misses you. I just want him to be safe. I hope that you understand.

Mediator: And Dušan will be happy only if he sees that his mom and dad are doing well. Children do best when they have contact with both parents. Ok, today's session is over. If you agree, I would like us to meet again in a few days. Do you both agree to that?

Saša: Of course.

Iva: Yes.

Mediator: I hope that next time we can move forward. We have to come up with a schedule that would state when each one of you will spend time with Dušan. Please think about that until our next meeting.

Iva (on their way out): Would you like to come and see Dušan tonight? He would love to see you. Saša: Ok, I will. 


\subsubsection{Analysis}

In this mediation the mediator's role was quite passive. Most of the time during the session, the parties were allowed to express their positions and feelings without the mediator interrupting. The mediator would get involved only when he felt it was necessary, i.e., to reflect and summarize what the parties had just said or when they were stuck in a circle of repeating the same accusations over and over again. For example, when Iva said that she did not have a problem with Saša but rather with Ana who might harm Dušan, mediator reflected that in a more neutral language by saying: "I hear you saying that you don't consider Saša a bad father but rather that you are concerned about Dušan's safety with Ana in the house." By doing this, the mediator shaped Iva's words from aggressive to more neutral, so that Saša could hear them in a different, better way. The purpose was to start a process of empowering Saša, so that he could understand Iva's position and interests. After Saša admitted that he understood some of Iva's concerns, Iva was ready as well to consider other options for Saša to be able to see Dušan. She admitted that Dušan missed Saša and that she did not want Dušan not to be able to see his father. The mediator also acknowledged the parties' feelings, for example, when he asked Saša how he felt about everything that was going on.

Everything described happened in a joint session. The mediator did not want to separate the parties even when the discussion between them was quite adversarial. Rather than doing that, the mediator reminded them that "they seemed fine outside in the lobby, talking and laughing." With this, the mediator wanted them to start giving reasons for their positions. He wanted them to focus on their interests because interests give rise to solutions while positions do not. That was the moment when both Saša and Iva stopped holding on to their positions and started sharing each other's interests and concerns. It was very important in helping the parties understand each other's points of view. Another very important moment occurred when Iva said that she would sometimes like them to take Dušan to the park together. The mediator then asked Saša if he would be comfortable with that arrangement. Saša recognized Iva's standpoint and agreed to consider her proposal.

Before mediation, Iva's position was: "Saša cannot see Dušan and nothing can make me change my mind!" Saša's position was: "I want to see my son!" By the end of the session, both of them were transformed through the process of "empowerment and recognition", and they were able to find options to resolve their conflict. Iva was willing to allow Saša to see Dušan in her home and to allow him to take Dušan out but not to his house. Saša was ready to accept that in order to be able to spent time with his son. Thus, the transformative approach is most likely the one that would lead Saša and Iva to a longterm parenting agreement that would serve the best interests of their child.

\section{CONCLUSION}

Each mediation style has its own strengths and weaknesses. Therefore, it is hard to support or oppose any of these styles without taking into account that every dispute is unique, just as the people involved in it. Therefore, it is significant that any particular mediation technique is valued with regard to the characteristics of the specific kind and circumstances of dispute that is to be resolved through mediation.

Taking this into consideration, in child custody disputes, we have to start from the fact that child custody mediation is based on the belief that parents know and want the best for 
their children. Even during difficult times of separation or divorce, even when they feel that they don't like, trust or respect each other any longer, they still have a lot to offer because, above all, they love their children and want the best for them. Mediation recognizes this and, among other things, it distinguishes mediation from the adversarial process.

Based on the belief that parents know and want the best for their children, it seems that the transformative model has many tools that will satisfy the specific needs of the parties in custody cases. The transformative approach gives more autonomy to the parties in making decisions about their parenting. Given that the parenting conflict carries a mixture of pain, blame and anger, it is also very helpful when the mediator acknowledges these feelings. Otherwise, the possibility of reaching any kind of agreement would be small. The positive feature of transformative and facilitative model is the recognition of the underlying emotional issues. The evaluative style ignores the emotional aspect of parental conflict, which may affect both the conflict and the outcome. The transformative model teaches parents how to recognize and understand each other's needs and interests, and equips them with skills that they can use for resolving future conflicts. It is very important in custody cases. Parents remain parents even after divorce or separation, and they have to be able to make decisions together about their child in the future, without getting into new conflicts. This is significant for the benefit of the child and the family as a whole.

However, both the facilitative and strictly transformative approach may lead to unfair results since the mediator relies on the parties' ability to resolve their own conflict. This is especially true in cases where the parties are not of the same power, for example, in case where the weaker parent is ready to accept something that would obviously harm the child. These cases need a more directive approach than the one offered in transformative or even facilitative model. The mediator should then play a more active role of the "child's advocate". As explained by Irving and Benjamin, "the mediator is there to advocate for neither spouse, but rather for the larger family system of which they are members, and especially for the children" (Irving, Benjamin, 1987: 54).

The mediator's role is also to assist the parents in finding options for their parenting agreement. However, this role should not assume evaluation of the parties' legal positions. Evaluation might be appropriate only if parents require it because they consider it helpful for making the right decision, and only under the assumption that the mediator has legal expertise in the area of custody law. Otherwise, the mediator's neutrality may be compromised by the evaluation which favors only one parent. The other parent might then assume a strong defensive position, which would only move the process backwards. If the parents do not request an evaluation, there is no need for the mediator to give his opinion on the parties' legal positions. Notably, custody mediation is based on the belief that parents, rather than judges or any other third party, know what is best for their children.

There is no single right approach to child custody mediation. A good custody mediator is the one who is able to combine different styles and sometimes use more or less directive approach if it is required by the specific circumstances of the case. However, the mediator should never be so direct that he loses his impartiality, and never so passive that he ignores the parties' destructive behavior that would decrease the possibility of reaching an agreement. This is a matter of balance, and a skillful mediator will always know which tools to use in order to achieve this goal. The purpose of custody mediation should be to lead the parties to a parenting agreement that will benefit both parents and children, particularly given the fact that it is the agreement that they, and not the mediator, will have to live with. They have to feel good about it because it will affect their life; therefore, it should be their decision. If that goal 
is achieved, and as long as the basic mediation principles are respected throughout the process, mediation will have served its purpose regardless of the technique used by the mediator.

\section{REFERENCES}

1. Alfini, J. J., (1991), Trashing, Bashing, and Hashing It Out: Is This the End of "Good Mediation"?, Florida State University Law Review, Vol. 19., No. 1., 1991 (pp. 47-75).

2. Arsić, J., (2009). Transformativna teorija konflikta i medijacija, (Transformative Theory of Conflict and Mediation), in Džamonja-Ignjatović, T., Žegarac, N. (ed.), Theoretical Foundations of Mediation: Perspectives and Contributions. Belgrade, Center for Applied Psychology (pp. 165-182).

3. Baruch Bush, R. A., Folger, J., (1994). The Promise of Mediation: Responding to Conflict Through Empowerment and Recognition, John Wiley \& Sons, New York.

4. Baruch Bush, R. A., Folger, J., (2005). The Promise of Mediation: Responding to Conflict Through Empowerment and Recognition, Revised Edition, John Wiley \& Sons, New York.

5. Baruch Bush, R. A., (2001). Handling Workplace Conflict: Why Transformative Mediation?, Hofstra Labor \& Employment Law Journal, Vol. 18., No. 2., 2001 (pp. 367-373).

6. Clarke-Stewart, A.; Brentano, C., (2006). Divorce: Causes and Consequences, Yale University Press, New Haven.

7. Family Act, Official Gazette RS, No. 18 (2005), 72 (2011) and 6 (2015).

8. Franks, M. F., (1983). Winning Custody, Prentice-Hall, Englewood Cliffs.

9. Friedman, G. J., (1993). A Guide to Divorce Mediation, Workman Publishing, New York.

10. Goldzband, M. G., (1985). Quality Time: Easing the Children through Divorce, McGraw-Hill, New York.

11. Irvin, H. H., Benjamin, M., (1987), Family Mediation: Theory and Practice of Dispute Resolution, Carswell, Toronto.

12. Levin, M. S., (2001). The Propriety of Evaluative Mediation: Concerns About the Nature of an Evaluative Opinion, Ohio State Journal on Dispute Resolution, Vol. 16., No. 2., 2001 (pp. 267-296).

13. Riskin, L., (1996). Understanding Mediator's Orientations, Strategies and Techniques: A Grid for the Perplexed, Harvard Negotiation Law Review, Vol. 1., No. 7., 1996 (pp. 7-51).

14. Saposnek, D. T., (1998). Mediating Child Custody Disputes, John Wiley \& Sons, New York.

15. Saposnek, D. T., (2001). How Language Shapes our Thinking: Towards A Parenting Plan, Retrieved 1 September, 2016, from http://mediate.com/articles/saposnek2.cfm.

16. Saposnek, D.T., (2003). Children's Reactions to the News of Divorce: What They Need from You, Retrieved 1 September, 2016, from http://www.mediate.com/articles/saposnek3.cfm.

17. Saposnek, D. T., Rose C., The Psychology of Divorce (2004), Retrieved 1 September, 2016, from http://www.mediate.com/articles/saporo.cfm.

18. Schepard, A. I., (2004). Children, Courts and Custody: Interdisciplinary Models for Divorcing Families, Cambridge University Press, New York.

19. Wallerstein, J. S., Lewis, J. M., Blakeslee, S., (2000). The Unexpected Legacy of Divorce: A 25 Year Landmark Study, Hyperion, New York.

20. Zumeta, Z. D., (2000). Styles of Mediation: Facilitative, Evaluative and Transformative Mediation, Retrieved 20 September 2016, from http://www.mediate.com/articles/zumeta.cfm

21. Zumeta, Z. D., (2000). A Facilitative Mediator Responds, Journal of Dispute Resolution, Vol. 2000, No. 2., 2000, pp. 335-341.

22. Porodični zakon (Family Act), Službeni glasnik RS, 18/2005, 72/2011 and 6/2015.

23. Zakon o posredovanju u rešavanju sporova (Mediation Act), Službeni glasnik RS, 55/2014

24. Republički zavod za statistiku Republike Srbije (Statistical Office of the Republic of Serbia, Marriages and Divorces, 2015, Press Release, 30 June 2016, Retrieved 3 September, 2016, from http://webrzs.stat.gov.rs/ WebSite/public/PageView.aspx?pKey=711\&URL=http://pod2.stat.gov.rs/ElektronskaBiblioteka2/Pretraga_EB. aspx?pubType=2. 


\section{PORODICE I MEDIJACIJA: EFEKAT RAZLIČITIH STILOVA MEDIJACIJE U SPOROVIMA O VRŠENJU RODITELJSKOG PRAVA}

Sporovi o vršenju roditeljskog prava mogu se vezivati za različite pravne situacije, kao što su: razvod, starateljstvo, usvojenje, zlostavljanje $i$ zanemarivanje deteta i drugo. Ipak, sporna pitanja u pogledu vršenja roditeljskog prava najčešće uzrokuju slučajevi razdvajanja i razvoda roditelja. Porodice koje se suočavaju sa ovim stresnim životnim događajima prolaze kroz težak period nesigurnosti i razočaranja. Istraživanja ukazuju da stepen saradnje, odnosno sukoba između roditelja predstavlja faktor koji prevashodno određuje način na koji dete reaguje na razvod i prestanak zajednice života roditelja. Nažalost, sudski postupak se nije pokazao kao metod rešavanja sporova koji podstiče saradnju između roditelja u pogledu staranja o detetu. Za razliku od sudskog postupka, medijacija se potvrdila kao proces koji umanjuje negativne posledice koje uobičajeno proističu iz sporova o vršenju roditeljskog prava. Medijacija spaja roditelje, ističe njihove zajedničke interese, i pomaže im u donošenju odluka koje doprinose dobrobiti porodice. U poslednjih nekoliko decenija, u međunarodnoj praksi je razvijeno više stilova medijacije koji se danas koriste za rešavanje različitih vrsti sporova. Ovaj rad predstavlja jednu od najčešće diskutovanih klasifikacija stilova medijacije, sa ciljem utvrđivanja koji od navedenih pristupa najviše odgovara prirodi sporova o vršenju roditeljskog prava.

Ključne reči: dete, roditelj, spor o vršenju roditeljskog prava, medijacija, stil medijatora 